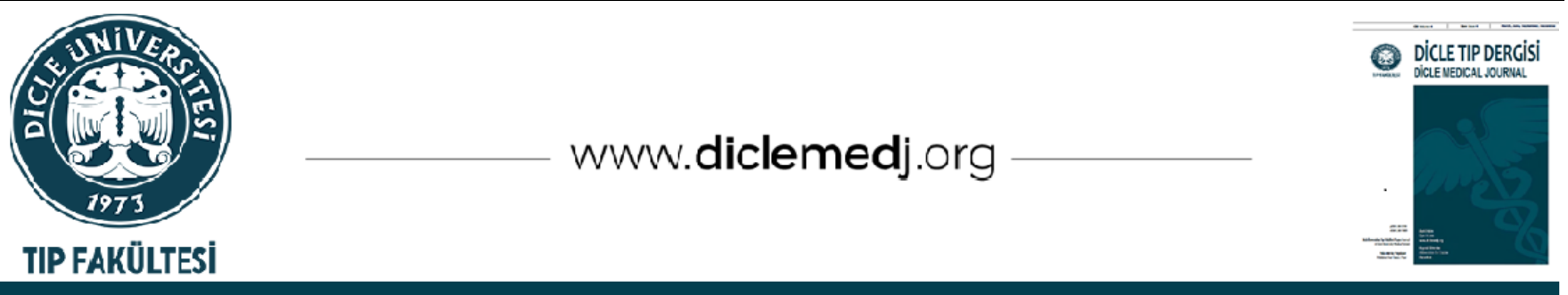

Original Article / Özgün Araştırma

\title{
The Diagnostic Accuracy of Abbreviated Breast Magnetic Resonance Imaging (Abbreviated Breast MRI)
}

\author{
Turkan Ikizceli ${ }^{1}{ }_{1}$, Gokce Gulsen ${ }^{2}$ \\ 1 University of Health Sciences, Istanbul Haseki Training and Research Hospital, Department of Radiology, Istanbul, Turkey \\ 2 University of Health Sciences, Istanbul Haseki Training and Research Hospital, Department of Radiology, Istanbul, Turkey \\ Received: 04.03.2021; Revised: 24.07.2021; Accepted: 27.07.2021
}

\begin{abstract}
Objective: Abbreviated Breast Magnetic Resonance Imaging (MRI) is a fast and a selected scan, used for screening women at high risk of breast cancer. The objective of this study is to assess the diagnostic accuracy of a new shortened Abbreviated Protocol (AP) relative to Full Diagnostic Protocol (FDP).

Methods: 206 breast MRIs were evaluated, respectively. AP was derived from the FDP and re-recorded. The new report was compared with the report of the previous FDP. The interpretation time of the shortened protocol was recorded. The results of the two protocols in terms of finding the lesion were compared using sensitivity, specificity, NPV, and PPV according to the histopathology results.

Results: 124 of 206 MRIs were malignant and 82 of 206 MRIs were benign. The average interpretation time was 58 $\pm 35 \mathrm{~s}$ with AP. The MIP sequence evaluation time was only $17 \pm 12 \mathrm{~s}$. The PPV, NPV, sensitivity and specificity values for AP MRI were $93.0 \%, 94.8 \%, 96.77 \%, 96.8 \%$ and $89.0 \%$ respectively. The PPV, NPV, sensitivity and specificity values for FDP MRI were $94.5 \%, 96.2 \%, 97.6 \%$ and $91.5 \%$ respectively. There was no significant difference in sensitivity and specificity for both protocols $(\mathrm{p}<0.05)$.

Conclusion: AP is a new and shorter version of a Breast MRI. The diagnostic accuracy of abbreviated breast MRI for the detection of breast lesions shows a high level of sensitivity and specificity, with the advantages of shortening both the exam time and the interpretation time.
\end{abstract}

Keywords: abbreviated breast protocol, full diagnostic protocol, breast lesions, magnetic resonance imaging, breast screening

DOI: 10.5798/dicletip.987912

Correspondence / Yazışma Adresi: Turkan Ikizceli, University of Health Sciences Haseki Training and Research Hospital; Adnan Adivar Street, Number:9, 34130, Fatih, Istanbul/Turkey e-mail: ikizceli@yahoo.com, turkan.ikizceli@sbu.edu.tr 


\section{Kısaltılmış Meme Manyetik Rezonans Görüntülemenin Tanısal Doğruluğu (Kısaltılmış Meme MRG)}

Öz

Amaç: Kısaltılmış Meme Manyetik Rezonans Görüntüleme (MRG), yüksek meme kanseri riski taşıyan kadınları taramak için kullanılan hızlı ve seçilmiş bir MRG taramasıdır. Bu çalışmanın amacı, nihai histopatolojiye dayalı olarak tam tanı protokolüne (FDP) göre yeni bir kısaltılmış kısaltılmış protokolün (AP) tanısal doğruluğunu değerlendirmektir.

Yöntemler: Meme lezyonu olan sırasıyla 206 meme MRG retrospektif olarak değerlendirildi. FDP içinden AP türetildi ve yeniden raporlandı. Önceki tam standart tanısal MRI protokolünün raporu ile karşılaştırıldı. Kısaltılmış protokolün yorumlama süresi kaydedildi. Memede lezyonun bulunması açısından iki protokolün sonuçları altın standart histopatoloji sonuçlarına göre duyarlılık, özgüllük, NPV ve PPV kullanılarak karşılaştırıldı.

Bulgular: Histopatolojik sonuçlara göre 206 MRG'den 124'ü malign, 206 MRG'den 82'si benign idi. Ortalama yorumlama süresi AP ile $58 \pm 35$ sn idi. MIP sekans değerlendirme süresi yalnızca $17 \pm 12$ saniyeydi. AP MRG için PPV, NPV, duyarlılık ve özgüllük değerleri sırasıyla \%93,0, \%94,8, \%96,77, \%96,8 ve \%89,0 idi. FDP MRG için PPV, NPV, duyarlılık ve özgüllük değerleri sırasıyla \%94,5, \%96,2, \%97,6 ve \%91,5 idi. Her iki protokol arasında özgüllük ve duyarlılık açısından anlamlı bir fark yoktu $(\mathrm{p}<0.05)$.

Sonuç: AP, Meme MRG incelemesinin daha kısa ve yeni bir versiyonudur. Kısaltılmış meme MRG'nin meme lezyonlarının tespiti için tanısal doğruluğu, hem MRG elde etme süresini hem de yorumlama süresini kısaltmanın avantajları ile yüksek düzeyde duyarlılık ve özgüllük göstermektedir.

Anahtar kelimeler: kısaltılmış meme protokolü, tam tanı protokolü, meme lezyonları, manyetik rezonans görüntüleme, meme taramasl.

\section{INTRODUCTION}

Magnetic resonance imaging (MRI) is one of the most sensitive imaging modalities in breast imaging, particularly for screening women at high risk of breast cancer ${ }^{1}$. MRI has a higher potential as a soft tissue imaging modality in detecting breast lesions. Also, MRI does not involve hazardous ionizing radiation like mammography. However, breast MRI is an examination that requires the use of a contrast agent, and interpreting the FDP takes time and requires a senior radiologist ${ }^{2}$. Nevertheless, there has been a gradual increase in the use of breast MRI for breast cancer screening in women at high risk. MRI is now used as a screening modality ${ }^{3}$. But, the use of MRI is a costly procedure directly and indirectly. The most important reason for this high cost is that the FDPs take a lot of time to acquire and read. An FDP takes nearly 20-60 minutes and consists of hundreds of images 4 . The idea of the abbreviated protocol (AP) for breast MRI was developed by Kuhl et al. in 2014 to reduce the image acquisition and reporting time. Kuhl et al. used only one pre-contrast, one first postcontrast subtracted sequence, and the maximum-intensity projection images (MIP) with dynamic images derived from them. The AP seemed capable of reducing the standard costs associated with the same diagnostic accuracy and cancer detection. As a result, AP is a potential future cancer screening tool for larger populations of women with high-risk for breast cancer5-9.

The objective of this study is to assess the diagnostic accuracy of a new shortened AP protocol relative to FDP based on the classification of the Breast Imaging Data and Reporting System (BI-RADS).

\section{METHODS}

Patient Selection: This study was conducted at Haseki Training and Research Hospital, after approval by our institutional review board (2020-103). Informed written consent was obtained from all patients before any 
interventional procedures. Patients with breast masses who declined core-needle biopsies were excluded from this study. From August 2017 to August 2018, we evaluated our database and identified 206 MRIs retrospectively that were classified as American College of Radiology (ACR) categories 3 to 5 . The mean age was $45.79 \pm 12.46$ years (age range: 21-93 years). The indications for breast MRI were preoperative assessment of breast cancer, suspected breast lesions, high-risk women (patients with positive family history and BRCA1 or BRCA-2 mutations) for breast cancer screening whose mass was detected by ultrasound, axillary lymph nodes, an unknown primary malignancy, and nipple discharge. MRI could not be performed for patients suffering from claustrophobia, patients with renal problems who could not receive contrast material, and patients who could not lie in the prone position. All patients underwent ultrasound-guided biopsies using 16-gauge automatic needles (GEOTEK, Ankara, Turkey) and were histopathologically tested.

Data Acquisition: Breast MRI was performed in a 1.5Tesla MRI (Achieva Philips, The Netherlands) while patients were in the prone position and eight-channel breast coils were used. FDP included axial non-fat-suppressed T1-weighted and axial T2-weighted acquisition before injection of gadolinium (TR:550 ms TE: $10 \mathrm{~ms}$ THK: $3 \mathrm{~mm}$, FOV: $300 \mathrm{~mm}$ NSA: 2 T:1.55 min), T2 STIR (TR: $4000 \mathrm{~ms}$ TE: $125 \mathrm{~ms}$ FOV $300 \mathrm{~mm}$ NSA:2 T: $1.40 \mathrm{~min}$ ). Contrastenhanced images were obtained with $\mathrm{T} 1$ FATSET and THRIVE sequences (TR: $550 \mathrm{~ms}$ TE: 10 ms THK: 3 mm, FOV: 300 mm FA: 20 NSA: 2 T: $5.55 \mathrm{~min}$ ) in the axial plane. Subtracted images from both series after injection and MIP images from these subtractions were also obtained. Diffusion MRI was obtained by following main sequences and ADC was calculated automatically. Three-dimensional gradients were applied to $\mathrm{b}$ values of 0 and 800 $\mathrm{sec} / \mathrm{mm} 2$. Isotropic diffusion-weighted images were reconstructed for these $b$ values

A new AP was derived from the previous standard diagnostic MRIs that were included in the study. The AP consisted of pre-contrast T1weighted images, first derived post-contrast images, and MIP images. Lesion sizes were measured on MIP images.

Image Analysis: Based on the MRI findings, the lesions were classified into the BI-RADS categories of the American College of Radiology BI-RADS lexicon, without knowledge of the final pathological result. Unaware of the previous FDP, AP was reported again blindly. The MRI reports were analyzed by a consulting radiologist (T.I., ten years of experience in breast radiology). The interpretation time and BI-RADS category were re-recorded for the AP. The results of the two protocols in terms of finding the lesion in the breast and according to the BI-RADS category were compared using sensitivity, specificity, negative predictive value (NPV), and positive predictive value (PPV) according to the gold standard histopathology results.

Statistical Analysis: SPSS 15.0 for Windows program (SPSS Inc. Chicago, IL, USA) was used for statistical analysis. Descriptive statistics; number and percentage for categorical variables, and numerical variables as mean, standard deviation, minimum, maximum, median. The rates independent groups were compared with McNemar Test. Compliance assessment was done by kappa value. Since numerical variables did not meet the normal distribution condition, comparisons of two independent groups were made using the Mann Whitney U Test. Statistical significance levels of alpha were accepted as $\mathrm{p}<0.05$.

\section{RESULTS}

According to the histopathological results, 124 of 206 MRIs were malignant and 82 were benign. Twenty-one MRI had multiple lesions 
(15 malignant, 7 benign lesions). Mean lesion size was $29,7 \pm 20,9 \mathrm{~mm}(7-100 \mathrm{~mm})$ for benign lesions, and 22.92 $\pm 13.90 \quad(7-85 \mathrm{~mm})$ for malignant lesions (Fig. 1a-d, 2 a, b). Demographic data are shown in Table I.

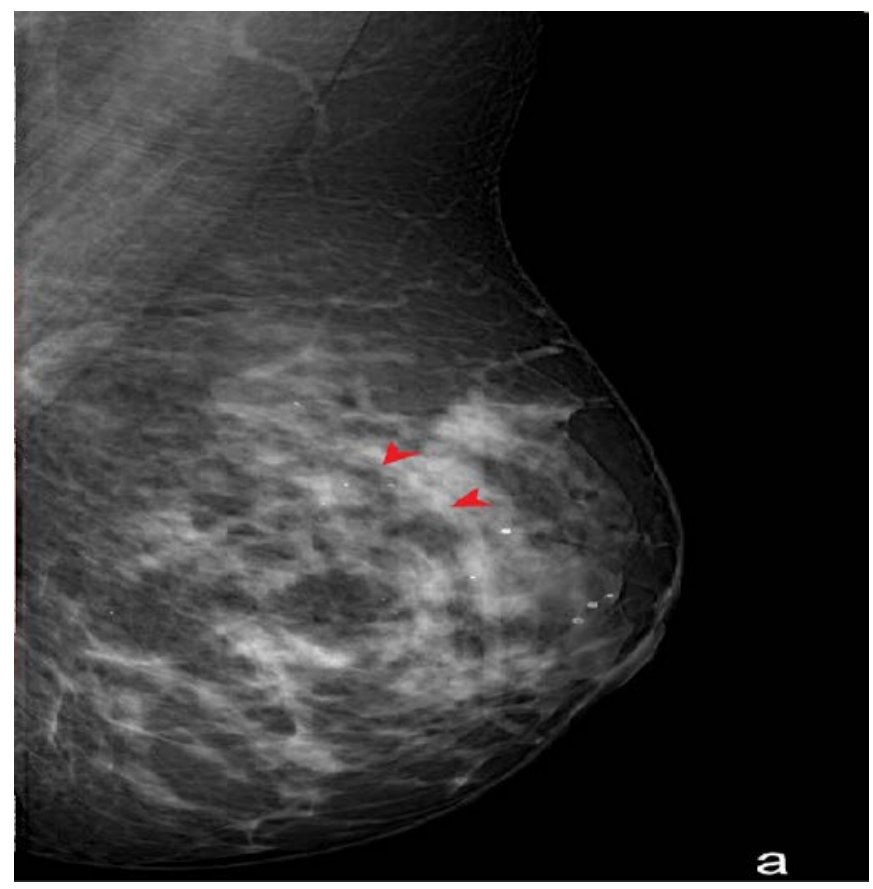

Figure 1: A 42-year-old woman with a family history; (a) left MLO mammogram shows non-specific macrocalcifications that did not change from previous years

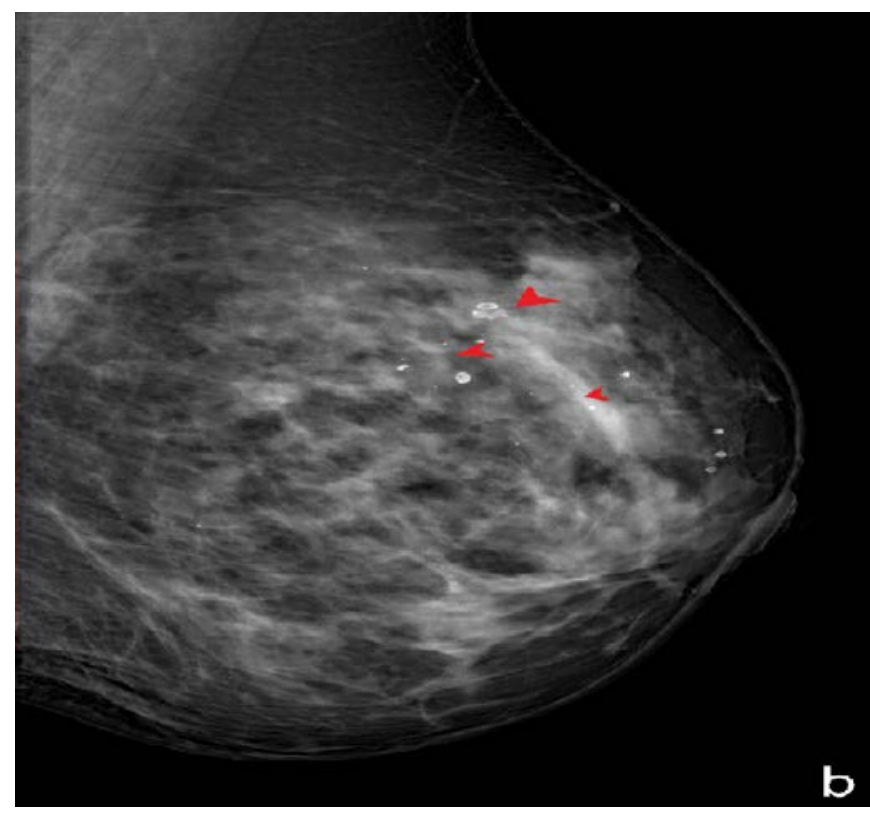

Figure 1: (b) After one year of follow-up mammography, a few newly-developed micro-calcifications and especially increased macrocalcifications are seen. The lesion was not seen on sonographic correlation

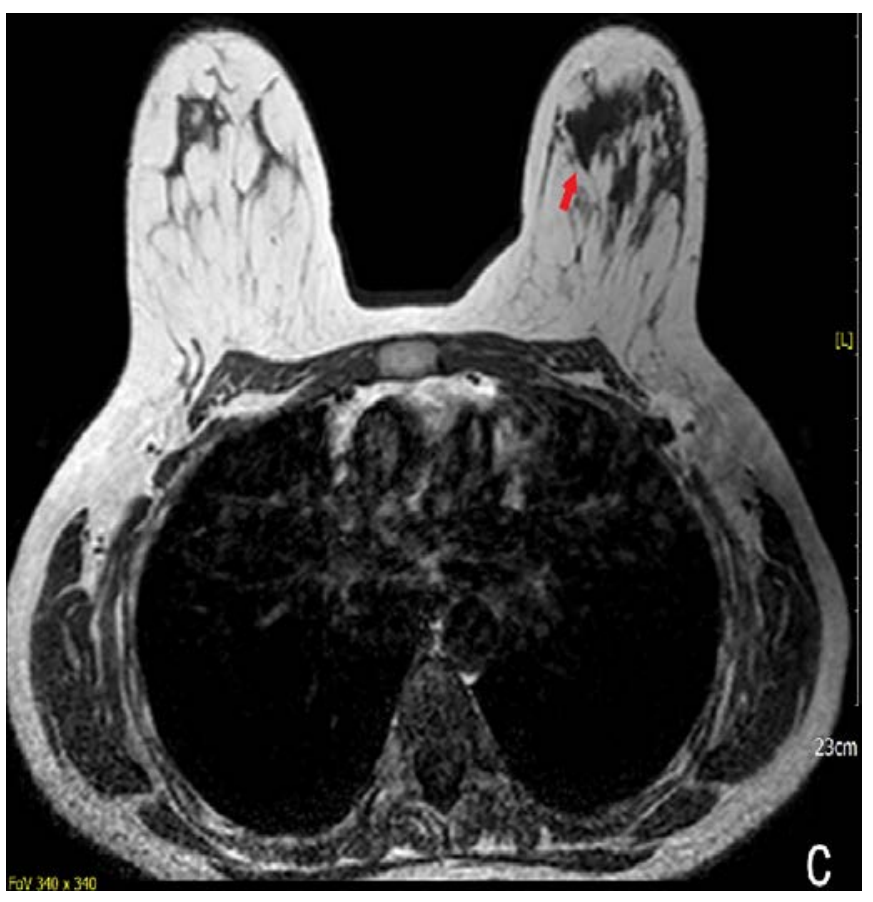

Figure 1: (c) MRI: Axial T1-weighted sequence before contrast agent injection (pre-contrast sequence)

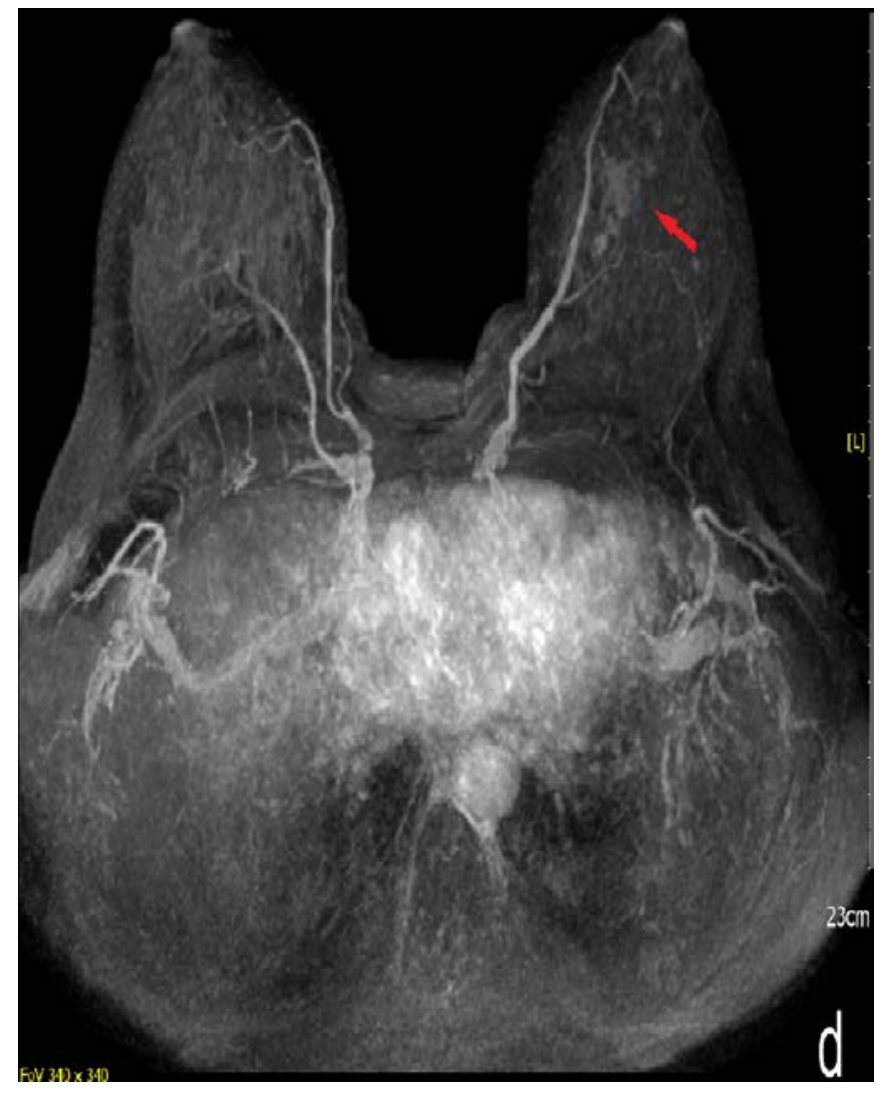

Figure 1: (d) MIP sequence shows the invisible cancer in the left breast much more clearly with its actual size. 


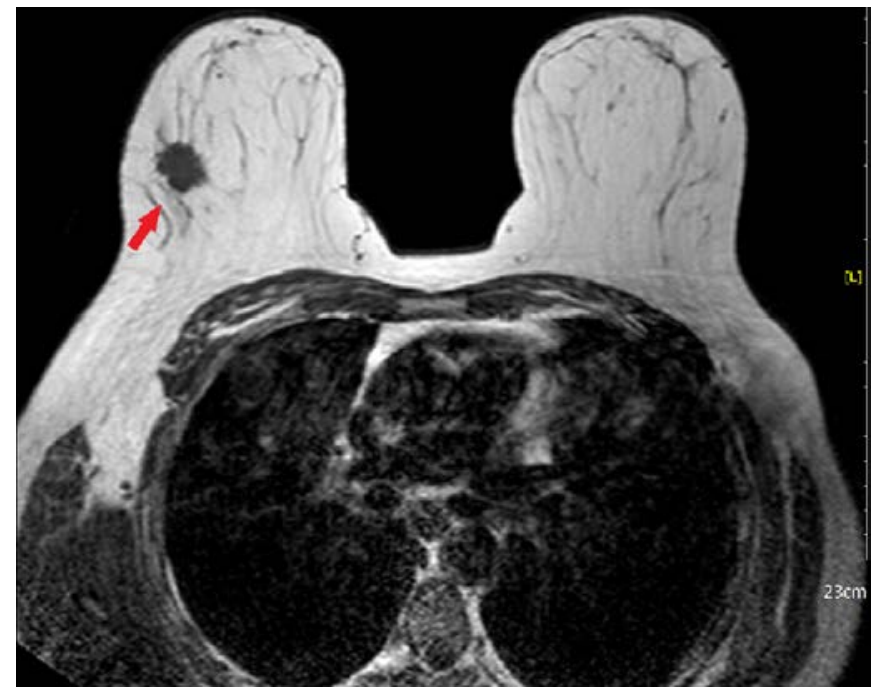

Figure 2: A 44-year-old female patient with biopsyproven breast cancer (a) MRI: Axial T1-weighted sequence pre-contrast sequence

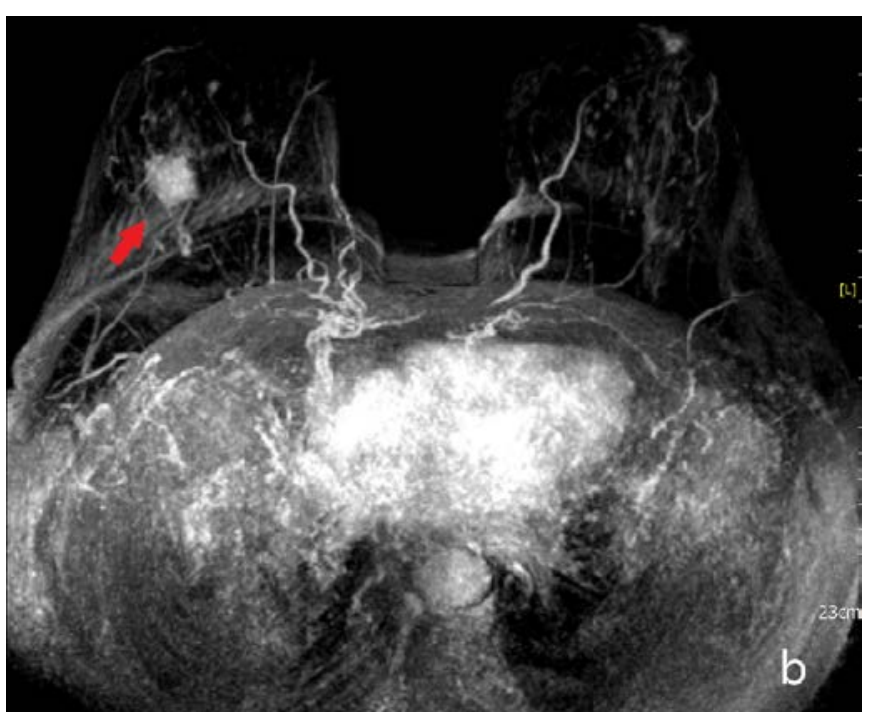

Figure 2: (b) MIP shows the tumor very clearly.

Tablo I: Demographic data

\begin{tabular}{|c|c|c|c|c|c|c|c|}
\hline \multicolumn{8}{|c|}{ Histopathology } \\
\hline & \multicolumn{2}{|c|}{ Total } & \multicolumn{2}{|c|}{ Benign $(n=82)$} & \multicolumn{2}{|c|}{ Malignant ( $n=124)$} & \multirow[b]{2}{*}{$p$} \\
\hline & Mean. $\pm S D$ & Min-Max (Median) & Mean. $\pm S D$ & $\begin{array}{l}\text { Min-Max } \\
\text { (Median) }\end{array}$ & Mean. $\pm S D$ & Min-Max (Median) & \\
\hline Age & $45.8 \pm 12.5$ & $21-93(45)$ & $40.4 \pm 10.8$ & $21-66$ (39.5) & $49.4 \pm 12.2$ & $28-93(45.5)$ & $<0.001$ \\
\hline Size & $25.6 \pm 17.3$ & $7-100(21)$ & $29.7 \pm 20.9$ & $7-100(22)$ & $22.9 \pm 13.9$ & $7-85(20)$ & 0.048 \\
\hline AP & $3.40 \pm 1.02$ & $2-5(4)$ & $2.37 \pm 0.64$ & $2-4(2)$ & $4.08 \pm 0.52$ & $2-5(4)$ & $<0.001$ \\
\hline FDP & $3.69 \pm 1.37$ & $2-5(4)$ & $2.12 \pm 0.40$ & $2-4(2)$ & $4.73 \pm 0.54$ & $2-5(5)$ & $<0.001$ \\
\hline
\end{tabular}

AP: Abbreviated Protocol, FDP: Full Diagnostic Protocol

When the results of both protocols were compared with histopathological results, 77 of 82 lesions in AP-MRIs and 78 of the FDP-MRIs were considered benign.

When the results of both protocols were compared with histopathological results, 82 histopathologically proven lesions, 77 lesions for AP-MRI, and 78 lesions for FDP-MRI, were considered benign respectively. 124 histopathologically proven malignant lesions, 129 for AP-MRI, and 128 lesions for FDP-MRI were considered malignant. McNemar Test for AP was 0.267, Kappa value was 0.867, while for FDP it was 0.344 and 0.898 , respectively. The distribution of MRIs reported separately according to both protocols according to the gold standard histopathology results is given in Table II.

Table II: AP and FDP results according to the gold standard histopathology results.

\begin{tabular}{|l|c|c|c|c|c|c|}
\hline & \multicolumn{2}{|c|}{$\begin{array}{c}\text { Benign } \\
\text { (n/\%) }\end{array}$} & \multicolumn{2}{l|}{$\begin{array}{l}\text { Malignant } \\
\text { (n/\%) }\end{array}$} & $\begin{array}{c}\text { McNemar } \\
\text { Test p }\end{array}$ & Kappa \\
Value
\end{tabular}

When both protocols are classified according to BI-RADS lexicon, BI-RADS category 2 for AP; 63 (30.6\%), BI-RADS category 3; 16 (7.8\%), BIRADS category 4; 109 (52.9\%), BI-RADS 
category 5; 8 (8.7\%) were re-recorded. BI-RADS category 2 for FDP; 75 (36.4\%), BI-RADS category 3; 9 (4.4\%), BI-RADS category 4; 26 (12.6\%), BI-RADS category 5; 96 (46.6\%) reports were obtained. Although there is a significant difference between BI-RADS category 4 and 5 for both protocols, the number of lesions that require a total biopsy (BI-RADScategory 4 and 5) was 127 (61.6\%) for AP and 122 (59.2\%) for FDP. The BI-RADS classification according to both protocols is given in Graphic 1.

Graphic 1. BI-RADS category $(2,3,4,5)$ classification of breast MR using complete and abbreviated protocols.

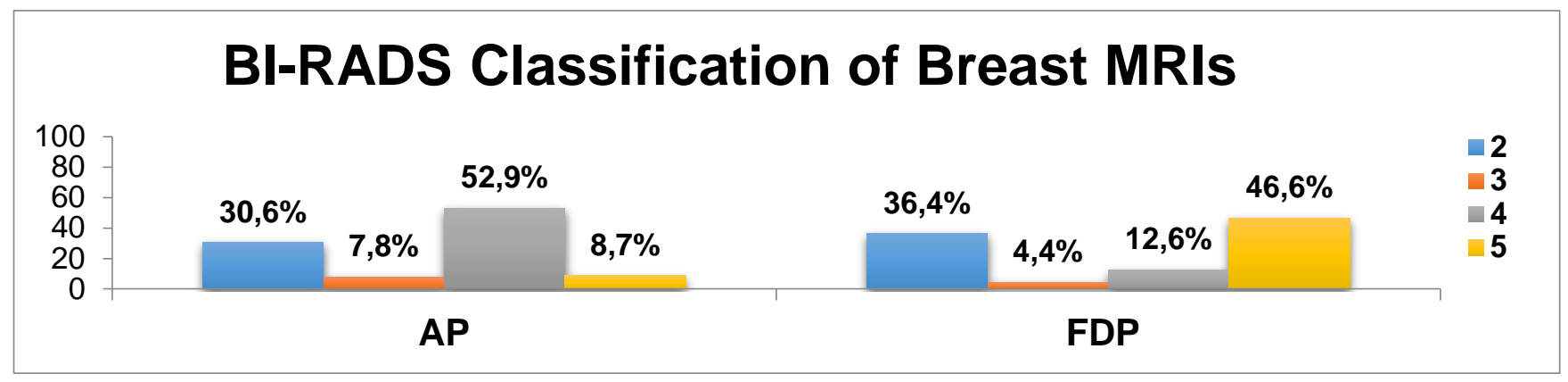

BI-RADS: Breast Imaging-Reporting and Data System, AP: Abbreviated Protocol, FDP: Full Diagnostic Protocol

Reading time was significantly lower with AP compared to the full protocol. The average interpretation time was $58 \pm 35 \mathrm{~s}$ with the AP. The MIP sequence evaluation time was only $17 \pm 12$ seconds. The PPV, NPV, sensitivity and specificity values for AP MRI were 93.0\%, $94.8 \%, 96.77 \%, 96.8 \%$ and $89.0 \%$ respectively. The PPV, NPV, sensitivity and specificity values for FDP MRI were 94.5\%, 96.2\%, 97.6\% and 91.5\% respectively (Table III). There was no significant difference in specificity between the abbreviated or FDP $(\mathrm{p}<0.5)$ protocols.

Table III: Diagnostic performance and accuracy of FDP and AP-MRI

\begin{tabular}{|l|c|c|c|c|c|}
\hline & $\begin{array}{c}\text { Sensitivit } \\
\mathbf{y}(\mathbf{\%})\end{array}$ & $\begin{array}{c}\text { Specificit } \\
\mathbf{y}(\%)\end{array}$ & $\begin{array}{c}\text { PPV } \\
\mathbf{( \% )}\end{array}$ & $\begin{array}{c}\text { NPV } \\
\mathbf{( \% )}\end{array}$ & $\begin{array}{c}\text { Accurate } \\
\text { knowledge (\%) }\end{array}$ \\
\hline $\begin{array}{l}\text { A } \\
\mathbf{P}\end{array}$ & 96.8 & 89.0 & 93.0 & 94.8 & 93.7 \\
\hline $\begin{array}{l}\mathbf{F} \\
\mathbf{D} \\
\mathbf{P}\end{array}$ & 97.6 & 91.5 & 94.5 & 96.2 & 95.2 \\
\hline
\end{tabular}

\section{DISCUSSION}

Mammography is a commonly used breast cancer screening tool and is the only imaging modality proven to reduce the breast cancer death rate from $25 \%$ to $40 \%$ in multiple prospective randomized clinical trials worldwide ${ }^{10,11}$. For breast cancer, the first step is still screening mammography. However, decreases in mammographic sensitivity is especially a problem in young women and women who have dense breast tissue. Also, screening with mammography involves large limitations for women who have a high risk for breast cancer with BRCA1 and BRCA2 mutations ${ }^{12}$.

Although MRI is the most sensitive imaging method for breast cancer, it is accepted as a second-step imaging method and as an additional method and problem solver after mammography ${ }^{13,14}$. In recent years, breast cancer screening has become widespread with MRI, which is applied to high-risk groups especially for breast cancer ${ }^{15}$. In this way, breast cancer is detected earlier.

Breast cancer screening with breast MRI not only results in higher sensitivity (71-100\%) than mammography (13-59\%) and ultrasound (13-65\%) but also detects a significant number of additional breast cancers (43\%). Compared to mammography and ultrasound, it is more 
sensitive to lesions less than $1 \mathrm{~cm}$ detected during mammography $(\mathrm{p}<0.001)^{16}$. The most important benefit of MRI is that, while detecting these additional cancers, it is not affected by dense breast structures, patient age, and operator dependence in youth ${ }^{17}$. Thus, millimetric lesions are detected in young women with dense breasts, and the patient is identified at the most critical early stage of breast cancer.

However, MRI is a highly technical and expensive imaging method with a long acquisition time ranging from 20 to 60 minutes. Patients need to lie motionless in the prone position for this long period. Claustrophobia is also a big problem. These are limiting factors in the use of the breast MRI as a screening method in large populations ${ }^{18,19}$. In another study of the ACRIN 6666 group by Berg et al., 42.1\% of the high-risk group refused breast MRI. Most of the participants reported that they refused owing to claustrophobia, length of acquisition time, and $\operatorname{cost}^{20}$.

The European Breast Imaging Association normally recommends obtaining pre-contrast T1-weighted and T2-weighted series for a full diagnostic protocol. They report that both postcontrast application and obtaining full dynamic sequences were the most important sequences. In addition, pre-contrast diffusion imaging has become a routine part of breast imaging. The most important feature of dynamic sequences provides morphological information about the lesion, as well as physiological information with time-intensity curves. In this way, the rapid washout feature, which is a malignant tumor feature, is detected ${ }^{1,21}$. In total, FDP consists of T2-weighted turbo spin-echo and T1-weighted turbo spin-echo axial, sagittal, and coronal sequences, diffusion, and five post-contrast enhanced series. Plus, FDP consists of several thousand sections and requires a lot of time and experience to read. The shortened protocol was derived from FDP and consisted of a single unenhanced, single contrast, generated subtraction, and a single MIP image ${ }^{22}$. In this form, breast MRI will be obtained in times similar to the time for mammography.

Kuhl et al. ${ }^{4}$ performed a retrospective study in which an FDP consisting of 8 different pulse sequences was obtained for a cohort of 443 women with a mildly elevated risk of breast cancer or dense breast tissue. They found that the specificity and positive predictive value of MRI-AB were equal to the FDP (94.3\% versus $93.9 \%$ and $24.8 \%$ versus $23.4 \%$ ). The negative predicted value for MRI-AB was 99.8\%. Parallel studies conducted after Kuhl et al. are available in the literature and have approximately the same results. Similar to the results in the literature, the results of our study found PPV, NPV, sensitivity, and specificity values for AP were $93.0 \%, 94.8 \%, 96.77 \%, 96.8 \%$, and $89.0 \%$ respectively. The PPV, NPV, sensitivity and specificity values for FDP MRI were 94.5\%, $96.2 \%, 97.6 \%$ and $91.5 \%$ respectively. The fact that the size of the lesion $(29,7 \pm 20,9 \mathrm{~mm}$ for benign lesions and $22.92 \pm 13.90$ for malignant lesions) may have caused the elevation in PPV rates. The high specificity values we found in our study compared to the literature are due to the fact that the majority of patients included in the study were malignant and the lesion sizes were large. Although the morphological features were not evaluated clearly according to FDP, our specificity values are high due to the presence of kinetic values. While our results show similar results in BI-RADS category 2 and 3 lesions classification, the difference in BIRADS category 4 and BI-RADS category 5 lesion definitions is that FDP defines the morphological and kinetic features of the lesion more. However, the results of both protocols with regards to the total number of lesions requiring biopsy (BI-RADS category 4 and BIRADS category 5) were similar. The major disadvantage of AP is that AP gives less information about the morphological features 
of the lesions. However, the use of AP for screening in high-risk groups in large populations is discussed here.

In the Kuhl study, while the FDP acquisition time was 17 minutes, AP was recorded as 3 minutes with reading time below 30 seconds. Similar results were obtained in many studies (Table IV) $4,5,23-25$. Especially, the MIP sequence had the fastest reading time in studies. In our study, the reading time was measured as $17 \pm 12$ seconds with the MIP sequence. It is a fact that radiologists experienced in breast radiology take a short time to read breast MRI. Our study is compatible with the studies in literature owing to the sensitivity of breast MRI and sensitivity of the MIP sequence. However, since the study was a retrospective study, MRI acquisition time could not be evaluated. This is a limitation of the study.

Table IV: Selected results from five studies of Abbreviated Protocols

\begin{tabular}{|c|c|c|c|c|c|c|c|c|c|c|}
\hline \multirow[b]{2}{*}{ References } & \multicolumn{2}{|c|}{$\begin{array}{c}\text { Average Reading } \\
\text { time } \\
(\mathrm{sec})\end{array}$} & \multicolumn{2}{|c|}{$\begin{array}{c}\text { Sensitivity } \\
(\%)\end{array}$} & \multicolumn{2}{|c|}{$\begin{array}{c}\text { Specificity } \\
\text { (\%) }\end{array}$} & \multicolumn{2}{|c|}{$\begin{array}{l}\text { PPV } \\
(\%)\end{array}$} & \multicolumn{2}{|c|}{$\begin{array}{l}\text { NPV } \\
(\%)\end{array}$} \\
\hline & FDP & AP & FDP & AP & FDP & $\mathrm{AP}$ & FDP & AP & FDP & AP \\
\hline Kuhl et al 4 & - & 28 & 100 & 100 & 93.9 & 94.3 & 23.4 & 24.4 & 100 & 100 \\
\hline Mango et al 23 & - & 44 & 100 & - & 96 & - & - & - & - & - \\
\hline Grimm et al 24 & 177 & 178.8 & 95 & 86.89 & 52 & 52.45 & - & - & - & - \\
\hline Harvey et al 5 & 385 & 93 & - & - & - & - & - & - & - & - \\
\hline Moschetta et al 25 & 360 & 120 & 92 & 89 & 92 & 91 & 68 & 64 & 98 & 98 \\
\hline
\end{tabular}

AP: Abbreviated Protocol, FDP: Full Diagnostic Protocol, PPV: Positive Predictive Value, NPV: Negative Predictive Value

With the AP protocol, the cost of MRI decreases indirectly due to the decrease in acquisition time and low time for reading. Despite all these, the technical part of the MRI examination, is more expensive than mammography, even with a short protocol, but young patients are in favor of MRI scanning due to the short reading time and the presence of a radiation-free cancer screening tool. A multi-center study, ACRIN 6666, conducted by Berg et al. reported that when ultrasound was used as a screening method, they found the acquisition time was 19 minutes. Also, due to the limitation of ultrasound which does not show microcalcification and has high false-positive rates, the cost and screening time increase when mammography is added to these patients. When MRI is added to the same group of women, it was observed that cancer detection efficiency increases significantly. Ultrasonography is recommended for patients who cannot tolerate $\mathrm{MRI}^{26-28}$. Considering the cost of MRI, it is clear that it will be beneficial only in the high-risk patient subgroup.

Limitations: The limitations of our study are that it was retrospective and the actual acquisition time for the AP could not be determined. The patient group selected were patients with masses. It was not performed with homogeneous high-risk group patients. 


\section{CONCLUSION}

The diagnostic accuracy of abbreviated breast MRI for detection of breast lesions has a high level of sensitivity and specificity, with the advantages of shortening both the exam time and the interpretation time. Based on our study, an abbreviated breast MRI protocol can be substituted for conventional MRI for breast cancer screening.

Ethics Committee Approval: This study was approved by Haseki Training and Research Hospital Ethics Committee (2020/103). It was conducted in accordance with the Helsinki Declaration, and informed consent was provided by all the participants.

Declaration of Conflicting Interests: The authors declare that they have no conflict of interest.

Financial Disclosure: No financial support was received.

\section{REFERENCES}

1. Mann RM, Balleyguier C, Baltzer PA, et al. The European Breast Cancer Coalition. Breast MRI: EUSOBI recommendations for women's information. Eur Radiol 2015; 25: 3669-78.

2. Kuhl CK. The current status of breast MR imaging part I. Choice of technique, image interpretation, diagnostic accuracy, and transfer to clinical practice. Radiology 2007; 244:356-78.

3. Warner E, Hill K, Causer P, et al. Prospective study of breast cancer incidence in women with a BRCA1 or BRCA2 mutation under surveillance with and without magnetic resonance imaging. J Clin Oncol 2011; 29: 1664-9.

4. Kuhl CK, Schrading S, Strobel K, et al. Abbreviated breast magnetic resonance imaging (MRI): first postcontrast subtracted images and maximumintensity projection-a novel approach to breast cancer screening with MRI. J Clin Oncol 2014; 32: 2304-10.

5. Harvey SC, Di Carlo PA, Lee B, et al. An Abbreviated protocol for high-risk screening breast MRI saves time and resources. J Am Coll Radiol 2016; 13: 7480.

6. Kuhl CK. Abbreviated breast MRI for screening women with dense breast: the EA1141 trial. Br J Radiol 2018; 91: 20170441.

7. Oldrini G, Fedida B, Poujol J, et al. Abbreviated breast magnetic resonance protocol: Value of highresolution temporal dynamic sequence to improve lesion characterization. Eur J Radiol 2017; 95: 17785.

8. Sheth D, Abe H. Abbreviated MRI and accelerated MRI for screening and diagnosis of breast cancer. Top Magn Reson Imaging 2017; 26: 183-9.

9. Greenwood HI. Abbreviated protocol breast MRI: The past, present, and future. Clin Imaging 2019; 53 : 169-73.

10. Mootz AR, Madhuranthakam AJ, Doğan B. Changing paradigms in breast cancers screening: Abbreviated Breast MRI. Eur J Breast Health 2019; 15: 1-6.

11. Tabar L, Yen MF, Vitak B, et al. Mammography service screening and mortality in breast cancer patients: 20-year follow-up before and after introduction of screening. Lancet 2003; 361: 140510.

12. Kriege M, Brekelmans CT, Boetes $C$, et al. Magnetic Resonance Imaging Screening Study G. Efficacy of MRI and mammography for breastcancer screening in women with a familial or genetic predisposition. N Engl J Med 2004; 351: 427-37.

13. Kuhl CK, Schrading S, Bieling HB, et al: MRI for diagnosis of pure ductal carcinoma in situ: A prospective observational study. Lancet 2007; 370: 485-92.

14. Sardanelli F, Podo F, Santoro F, et al. Multicenter surveillance of women at high genetic breast cancer risk using mammography, ultrasonography, and contrast-enhanced magnetic resonance imaging (the High Breast Cancer Risk Italian 1 study): Final results. Invest Radiol 2011; 46: 94-105.

15. Sardanelli F, Podo F. Breast MR imaging in women at high-risk of breast cancer. Is something changing in early breast cancer detection? Eur Radiol 2007; 17: 873-87. 
16. Warner E, Plewes DB, Shumak RS, et al. Comparison of breast magnetic resonance imaging, mammography, and ultrasound for surveillance of women at high risk for hereditary breast cancer. J Clin Oncol 2001; 19: 3524-31.

17. Riedl CC, Luft N, Bernhart C, et al. Triple-modality screening trial for familial breast cancer underlines the importance of magnetic resonance imaging and questions the role of mammography and ultrasound regardless of patient mutation status, age, and breast density. J Clin Oncol 2015; 33: 1128-35.

18. Lowry KP, Lee JM, Kong CY, et al. Annual screening strategies in BRCA1 and BRCA2 gene mutation carriers: A comparative effectiveness analysis. Cancer 2012; 18: 2021-30.

19. Dogan BE, Scoggins ME, Son JB, et al. American College of Radiology-Compliant short protocol Breast MRI for high-risk breast cancer screening: A prospective feasibility study. AJR Am J Roentgenol 2018; 210: 214-21.

20. Berg WA, Blume JD, Adams AM, et al. Reasons women at elevated risk of breast cancer refuse breast MR imaging screening: ACRIN 6666. Radiology 2010; 254: 79-87.

21. Mann RM, Kuhl CK, Kinkel K, et al. Breast MRI: guidelines from the European Society of Breast Imaging. Eur Radiol 2008; 18: 1307- 18.
22. Chhor CM, Mercado CL. Abbreviated MRI Protocols: Wave of the future for breast cancer screening. AJR 2017; 208: 284-9.

23. Mango VL, Morris EA, Dershaw DD, et al. Abbreviated protocol for Breast MRI: Are multiple sequences needed for cancer detection? Eur J Radiol 2015; 84: 65-70.

24. Grimm LJ, Soo MS, Yoon S, et al. Abbreviated screening protocol for breast MRI: a feasibility study. Acad Radiol 2015; 22: 1157-62.

25. Moschetta $M$, Telegrafo $M$, Rella $L$, et al. Abbreviated combined MR protocol: A new faster strategy for characterizing breast lesions. Clin Breast Cance. 2016; 16: 207-11.

26. Berg WA, Zhang Z, Lehrer D, et al. Detection of breast cancer with addition of annual screening ultrasound or a single screening MRI to mammography in women with elevated breast cancer risk. JAMA 2012; 307: 1394-404.

27. Berg WA, Blume JD, Cormack JB, et al. Combined screening with ultrasound and mammography vs mammography alone in women at elevated risk of breast cancer. JAMA 2008; 299: 2151-63.

28. Alan B, Kapan M, Girgin S. Retrospective analysis of 5100 mammography imaging in a tertiary university hospital Dicle Med J 2016; 43: 339-43. 